\author{
Дарко Илић, Срђан Стефановић, Слободан Јанковић
}

Медицински фракултет, Универзитет у Крагујевцу

\title{
QUALITY OF LIFE IN PATIENTS WITH MULTIPLE SCLEROSIS
}

\author{
Darko llić, Srđan Stefanović, Slobodan Janković
}

Medical Faculty, University of Kragujevac

Примљен/Received: 3.7.2011.

Прихваћен/Accepted: 17.10.2011.

\section{САЖЕТАК}

Увод: Мерење квалитета живота оболелих од мултипле склерозе (МC) од непроцењивог је значаја за одговарајућу процену степена тежине обољења, правилан избор терапије и праћење њених ефеката. Циљ овог рада био је да се процени квалитет живота оболелих од МС и утврде разлике у испитиваном исходу између пацијената различитог пола.

Пацијенти и методе: Спроведена је дескриптивна студија пресека у периоду од августа 2010. до маја 2011 године. Потребни подаци добијени су анонимним анкетирањем 110 пацијената. За процену квалитета живота коришћен је инструмент Светске здравствене организације "The World Health Organization Quality of Life (WHOQOL) - BREF". Подаци о полу и години рођења испитаника, затим о врсти МС, броју релапса болести у току последње 2 године, тренутној терапији коју пацијенти користе, дозном режиму лекова и новчаним средствима која болесници месечно издвајају за набавку лекова који се не издају на терет фонда здравственог осигурања, добијени су помоћу посебног структурисаног упитника. Прикупљени подаци анализирани су методама дескриптивне статистике и Студентовим Т-тестом за независне узорке.

Резултати: Од укупно 110 анкетираних испитаника $70 \%(\mathrm{n}=77)$ су чиниле жене, а $30 \%$ (n = 33) мушкарци. Није било стасти- стички значајне разлике међу испитаницима различитог пола о односу на дужину трајања болести, број рецидива у последње две године и новчана издвајања за лекове који се не издају на терет фонда здравственог осигурања у износу већем од 1000 динара месечно. Мерено WHOQOL-BREF профилом, код жена је свеукупно регистрован значајно бољи квалитет живота у односу на мушкарце $(\mathrm{p}=0,031)$, превасходно на рачун разлика у оцени аспеката непосредног животног окружења оболелих $(\mathrm{p}=0,025)$.

Закључак: У овој студији је показано да особе женског пола лакше подносе тегобе проузроковане мултиплом склерозом и имају бољи квалитет живота него мушкарци са истим клиничким обликом болести и идентичним тегобама, лечени истом терапијом.

Кључне речи: мултипла склероза, квалитет живота, WHOQOL - BREF

\section{ABSTRACT}

Background: Quality of life assessment in patients with Multiple sclerosis (MS) is invaluable for a proper evaluation of disease severity, appropriate choice of therapy and monitoring of its effects. The aim of this study was to assess the quality of life of patients with MS and to identify gender differences in examined outcome. 
Patients and Methods: A descriptive crosssectional study was conducted from August 2010 to May 2011. The data were obtained by anonymous survey of 110 patients. Quality of life of the patients was measured by the instrument "The World Health Organization Quality of Life (WHOQOL) - BREF". Data on gender and age of patients, type of MS, the number of relapses during the last 2 years, current therapy, dose regimens of certain drugs, and the amount of money the patients spend each month for the purchase of drugs that are not issued at the expense of health insurance fund, were obtained using a distinct structured questionnaire. The collected data were analyzed using simple descriptive statistics and Student's t-test for independent samples.

Results: Of the total 110 interviewed patients, 70\% ( $\mathrm{n}=77)$ were female and 30\% ( $\mathrm{n}$ $=33$ ) male. There were no significant gender differences in the disease duration, number of relapses in the last two years and spending of more than 1000 RSD per month for purchase of drugs that were not issued at the expense of the health insurance fund. Significantly better quality of life was recorded in women than men $(p=0.031)$, mainly on account of differences in the assessment of the domain of "Environment" ( $\mathrm{p}=$ 0.025), as measured by WHOQOL-BREF scale.

Conclusion: This study has shown that females tolerate difficulties caused by multiple sclerosis better than men, and also have a better quality of life than men with the same clinical form of the disease and identical symptoms, treated with the same therapy.

Кључне речи: Multiple sclerosis, Quality of life, recurrence, WHOQOL - BREF

\section{УВОД}

Мултипла склероза (МС) је хронична, прогресивна, запаљенска аутоимуна болест централног нервног система (ЦНС), варијабилног и непредвидивог клиничког тока са карактеристичном дисеминацијом симптома и знакова у времену и простору. Међу неуролошким обољењима она представља водећи узрок инвалидитета у популацији младих одра-слих особа и пацијената средњег животног доба. Основну пато-анатомску лезију код ове болести чине огњишта инфламације и демијелинизације нервног ткива (тзв. "плакови") расута по разним деловима мозга и кичмене мождине.

Скорија истраживања показала су да данас у свету од МС болује око 2.5 милиона људи, с тим да се током последњих деценија глобално бележи пораст инциденце ${ }^{1,2}$. Болест се око 2 пута чешће јавља код жена него код мушкараца, при чему претежно оболевају младе жене беле расе старости 20-40 година ${ }^{2}$. Према последњим публикованим подацима за нашу земљу, из 2001. године, преваленца МС у Србији износила је 41.5 случајева на 100.000 становника $^{3}$, што нас сврстава у регионе са високом учесталошћу ове ретке, али потенцијално веома тешке болести.

Мултипла склероза обично почиње изненада, и током времена испољава се обимном и разноврсном симптоматологијом са изражним индивидуалним варијацијама у зависности од степена захваћености појединих делова ЦНС-а и динамике прогресије. У крајњем стадијуму резултира трајном функционалном онеспособљеношћу и индиректно доводи до смртног исхода. Према клиничком току разликују се 4 типа МC, од којих је најзаступљенији тзв. релапсно-ремитентни облик болести (у 80-90\% случајева), који се карактерише наизменичном појавом и повлачењем симптома; већина нелечених пацијената временом развија секундарно прогресивни облик, док су примарно прогресивни и бенигни облик знатно ређи. Како се ради о неизлечивом обољењу непознатог узрока, основни терапијски циљеви усмерени су на ублажавање/отклањање симптома, успоравање напредовања болести и побољшање квалитета живота оболелих.

Узевши у обзир да су органска оштећења у $\mathrm{MC}$ непосредно повезана са поремећајима у психофизичком функционисању пацијента, мерење квалитета живота оболелих, које се односи на субјективно опажање физичких, социјалних и емоционалних аспеката стања болесника, од непроцењивог је значаја за одговарајућу процену степена тежине болести, правилан избор терапије и праћење њених ефеката ${ }^{4-6}$. Бројна истраживања су показала да уколико се процена првенствено заснива на објективним показатељима активности болести (физикалном налазу и налазу других уобичајених дијагностичких претрага), у великој мери се могу превидети и потценити стварни проблеми и потешкоће који ови болесници имају у вршењу уобичајених животних активности 4 .

У вези са претходно наведеним, основни циљ овог рада био је да се процени квалитет живота оболелих од МС и утврде разлике у 
испитиваном исходу између пацијената различитог пола.

\section{МЕТОДЕ}

Спроведена је дескриптивна студија пресека у временском периоду од августа 2010. године до маја 2011 године. Потребни подаци су добијени анонимним анкетирањем испитаника који су чланови Удружења оболелих од мултипле склерозе града Београда и Друштва мултипле склерозе Србије.

Анкетирање је спроведено на тзв. "згодном" узорку од укупно 110 испитаника. У истраживање су укључени пацијенти старији од 18 година, са истим, релапсно-ремитентним типом МС, без значајних психичких и когнитивних измена (пацијенти за које је процењено да могу дати валидне податке у упитнику). Искључујући критеријуми за учешће у студији били су: узраст до 18 година, изражени когнитивни и психички поремећаји, други клинички облик МС (примарно прогресивни, секундарно прогресивни или бенигни), трудноћа и дојење. Пацијенти мушког и женског пола усклађени су према старости, дужини трајања болести, броју релапса у последње две године, терапији коју користе и количини новчаних средстава које издвајају месечно за лекове који се не издају о трошку здравственог осигурања.

Величина узорка одређена је на основу следећих параметара: просечне очекиване разлике међу половима у укупном скору квалитета живота на скали коришћеног мерног инструмента од око 7 поена (10\%), уз стандардну девијацију од \pm 12 поена (величина ефекта $=0.58)$, затим нивоа статистичке значајности $\alpha$ од 0.05 и снаге студије од $80 \%$, за двосмерно статистичко тестирање значајности разлика између 2 независна узорка Студентовим Ттестом, при чему је узет однос броја мушкараца према женама 1:2, што је у складу са стварним разликама у преваленци МС међу половима. Прорачун је извршен помоћу посебног софтвера $\mathrm{G}^{*}$ Power $^{7}$.

За процену квалитета живота коришћен је инструмент Светске здравствене организације "The World Health Organization Quality of Life (WHOQOL) - BREF"', који је заправо генерички профил (скала) сачињен у уобичајеној форми упитника, и састоји се од укупно 26 питања о различитим аспектима квалитета живота пацијента у периоду претходне четири недеље. Питања су систематизована у четири подручја (домена), која се односе на физичко здравље, затим психолошке и социјалне аспекте квалитета живота појединца, као и чиниоце његовог непосредног животног окружења. Такође, постоје и два издвојена питања, где се од испитаника захтева да свеукупно оцени сопствени квалитет живота, односно задовољство постојећим здравственим стањем. На свако питање понуђено је пет одговора, од којих пацијент треба да заокружи један, онај за који сматра да најбоље одговара опису његовог стања. Одговори се вреднују бројчано, од 1 до 5, с тим да одговор који одражава најгори квалитет живота носи 1 бод, а најбољи 5 бодова. На крају се на посебан начин, помоћу одређених математичких манипулација, израчунава тзв. уобличени (трансформисани) скор за сваки домен посебно и укупни скор за испитаника (на скали 0-100), при чему је важно нагласити да што је вредност скора већа, квалитет живота је бољи и обрнуто.

Подаци о полу и години рођења испитаника, затим о врсти (клиничком облику) МC, броју релапса болести у току последње 2 године, тренутној терапији коју користе, дозном режиму појединих лекова и новчаним средствима која су им потребна за набавку лекова који се не издају на терет фонда здравственог осигурања за месец дана, добијени су помоћу посебног структурисаног упитника.

У статитистичкој обради резултата коришћене су методе дескриптивне статистике, попут средње вредности и стандардне варијације за континуалне варијабле, односно процентуалне учесталости испитаника са неком карактеристиком код описа категоријских варијабли. Значајност разлика између полова у основним карактеристикама, односно у измереном квалитету живота, испитивана је Студентовим Т-тестом за независне узорке, с обзиром да се у оба случаја радило о континуалним варијаблама. Резултати анализа сматрани су значајним за ниво вероватноћа нулте хипотезе мањи од 5\%. За све прорачуне коришћен је статистички програм SPSS (SPSS Inc., Chicago, IL), верзија 18.0.

\section{РЕЗУЛТАТИ}

Од укупно 110 анкетираних испитаника у наведеном временском периоду 70\% $(\mathrm{n}=77)$ чиниле су жене, а $30 \%(\mathrm{n}=33)$ мушкарци. Дужину трајања МC краћу од десет година навеле су 32 особе или $29,1 \%$, док је 78 испитаника или $70,1 \%$ навело да им болест траје дуже од десет година. Више од једног реци- 
дива болести у последње две године имале су 43 особе или $39,1 \%$ испитаника. Потрошњу финансијских средстава за лекове који се не издају о трошку фонда здравственог осигурања већу од 1000 динара месечно навело је
80 анкетираних или $72,8 \%$ од укупног броја испитаника. У погледу наведених обележја, није било статистички значајне разлике међу испитаницима различитог пола (Табела 1 ).

Табела 1. Разлике између мушкараца и жена оболелих од МС у погледу одређених карактеристика болести и њених последица (укључујући критеријуми)

\begin{tabular}{|c|c|c|c|c|c|}
\hline & $\begin{array}{l}\text { Пол испи- } \\
\text { таника }\end{array}$ & $\begin{array}{l}\text { Број испи- } \\
\text { таника }\end{array}$ & $\begin{array}{c}\text { Средња вредност } \\
\pm 1 \text { стандардна } \\
\text { девијација }\end{array}$ & $\begin{array}{c}\text { Студент-ов } \\
\text { Т-тест }\end{array}$ & $\begin{array}{c}\text { Статистичка } \\
\text { значајност }\end{array}$ \\
\hline \multirow{2}{*}{$\begin{array}{l}\text { Дужина трајања } \\
\text { мултипле } \\
\text { склерозе }\end{array}$} & $\mathrm{M}$ & 33 & $14,8 \pm 6,4$ & \multirow{2}{*}{$-0,474$} & \multirow{2}{*}{$\mathrm{p}=0,637$} \\
\hline & Ж & 77 & $15,3 \pm 5,5$ & & \\
\hline \multirow{2}{*}{$\begin{array}{l}\text { Број рецидива у } \\
\text { последње две } \\
\text { године }\end{array}$} & $\mathrm{M}$ & 33 & $1,15 \pm 1,3$ & \multirow{2}{*}{$-0,988$} & \multirow{2}{*}{$\mathrm{p}=0,328$} \\
\hline & Ж & 77 & $1,42 \pm 1,2$ & & \\
\hline \multirow{2}{*}{$\begin{array}{l}\text { Новчана } \\
\text { средства за } \\
\text { лекове који се не } \\
\text { издају о трошку } \\
\text { Р33О*-a }\end{array}$} & $\mathrm{M}$ & 33 & $2809,4 \pm 2171,6$ & \multirow[b]{2}{*}{0,656} & \multirow[b]{2}{*}{$\mathrm{p}=0,515$} \\
\hline & Ж & 77 & $2514,3 \pm 2061,7$ & & \\
\hline
\end{tabular}

* РЗ3О - Републички завод за здравствено осигурање

Мерено WHOQOL-BREF профилом, код жена је свеукупно регистрован значајно бољи квалитет живота у односу на мушкарце ( $\mathrm{p}=$ 0,031; Табела 2), превасходно на рачун разлика у оцени аспеката непосредног животног окружења оболелих ( $\mathrm{p}=0,025$; Табела 2). У оквиру овог домена, код пацијената оба пола, добијени су и најмањи просечни скорови (тј. најгоре вредности показатеља квалитета живота) међу свим испитиваним аспектима, док је најмањи негативан утицај болести на квалитет живота забележен у домену психолошких аспеката (Табела 2).

Табела 2. Упоређење квалитета живота мушкараца и жена оболелих од мултипле склерозе на скали WHOQOL-BREF

\begin{tabular}{|c|c|c|c|c|c|}
\hline $\begin{array}{l}\text { Домени } \\
\text { WHOQOL-BREF }\end{array}$ & Пол испитаника & $\begin{array}{c}\text { Број } \\
\text { испитаника }\end{array}$ & $\begin{array}{c}\text { Квалитет } \\
\text { живота на } \\
\text { скали } 0 \text { - } 100 \\
\end{array}$ & $\begin{array}{c}\text { Студент-ов } \\
\text { Т-тест }\end{array}$ & $\begin{array}{c}\text { Статистичка } \\
\text { значајност }\end{array}$ \\
\hline \multirow{2}{*}{$\begin{array}{l}\text { Физички аспекти } \\
\text { квалитета живота }\end{array}$} & M & 33 & $48,7 \pm 12.1$ & \multirow{2}{*}{$-1,794$} & \multirow{2}{*}{$p=0,078$} \\
\hline & Ж & 77 & $53,3 \pm 12.8$ & & \\
\hline \multirow{2}{*}{$\begin{array}{l}\text { Психолошки } \\
\text { аспекти } \\
\text { квалитета живота }\end{array}$} & $\mathrm{M}$ & 33 & $49,8 \pm 13.8$ & \multirow{2}{*}{$-1,984$} & \multirow{2}{*}{$\mathrm{p}=0,052$} \\
\hline & Ж & 77 & $55,6 \pm 13.9$ & & \\
\hline \multirow{2}{*}{$\begin{array}{l}\text { Друштвени } \\
\text { аспекти } \\
\text { квалитета живота }\end{array}$} & M & 33 & $54,3 \pm 19.0$ & \multirow{2}{*}{$-1,383$} & \multirow{2}{*}{$\mathrm{p}=0,172$} \\
\hline & Ж & 77 & $59,8 \pm 20.0$ & & \\
\hline \multirow{2}{*}{$\begin{array}{l}\text { Фактори } \\
\text { животне средине }\end{array}$} & M & 33 & $44,6 \pm 10.3$ & \multirow{2}{*}{$-2,276$} & \multirow{2}{*}{$\mathrm{p}=0,025^{*}$} \\
\hline & Ж & 77 & $50,2 \pm 14.9$ & & \\
\hline \multirow{2}{*}{$\begin{array}{l}\text { Укупан квалитет } \\
\text { живота }\end{array}$} & M & 33 & $76,1 \pm 11.8$ & \multirow{2}{*}{$-2,206$} & \multirow{2}{*}{$\mathrm{p}=0,031^{*}$} \\
\hline & Ж & 77 & $81,7 \pm 13.2$ & & \\
\hline
\end{tabular}

* Статистички значајна разлика

\section{ДИСКУСИЈА}

Одређивање квалитета живота код оболелих од МС подразумева оцену личне, физич- ке, материјалне и социјалне равнотеже. Сви ти параметри код ових болесника изражавају психичку стабилност, интелектуалну способ- 
ност, квалитет обављања свакодневних послова, изостанак бола и уклапања у социјалну заједницу као и осећај да је особа потребна заједници ${ }^{9}$. Многа истраживања су потврдила да скале које се односе на социјалну (друштвену) функцију, опште и ментално здравље и задовољство сексуалном функцијом у највећој мери одређују укупну оцену квалитета живота оболелих ${ }^{10}$.

Особе оболеле од МС често тврде да им ментално здравље и психички проблеми више утичу на квалитет живота од физичких погоршања и бола. Те констатације се доста разликују од схватања и лекара и осталог дела здраве популације. Функционални инвалидитет, депресија и умор су главне варијабле које се односе на доживљај физичких димензија здравља и болести; такође, и анксиозност и депресија саме по себи могу имати знатан негативни утицај на болесника са $\mathrm{MC}^{11}$. Дакле, може се претпоставити да лечење од умора, анксиозности и депресије повећава квалитет живота пацијента ${ }^{12}$.

Oceћај здравља свакако је најважнији фактор у процењивању квалитета живота оболелих од МС, али засигурно није и једини, што је потврђено у многим истраживањима код мушкараца, а посебно код жена ${ }^{13}$. У процени квалитета живота неопходно је уважити и осећај задовољства у животу болесника ${ }^{5}$; неке од значајних разлика између мушкараца и жена уочене су у погледу задовољства брачним животом, односно у погледу перцепције умора.

С обзиром да је МС веома непредвидива болест, врло је значајно да пацијент сачува психичку стабилност и да настави да живи и завршава свакодневне обавезе у складу са објективним могућностима. Такође је значајно да своја осећања дели са породицом, пријатељима и својим лекаром, а посебно са брачни другом ${ }^{14}$. Болест сама по себи изазива промене у организму које пацијента чине беспомоћним, уплашеним, депресивним и самим тим мења његов живот и улогу у породици ${ }^{15}$. Након утврђивања дијагнозе МС, пацијент и његова породица пролазе кроз тежак период привикавања на реалност присутне болести и њен ток ${ }^{16}$. Пацијенти у савладавању емоционалних проблема помоћ треба да затраже и у удружењима оболелих од мултипле склерозе која различито функционишу у појединим земљама ${ }^{17}$.

У свакој породици, у којој неко од чланова оболи од хроничне болести у почетку долази до забринутости, промена у расположењу и нарушавања свакодневне породичне хармоније; потребно је доста времена да се породица навикне на новонасталу ситуацију и врати у нормалне токове ${ }^{18}$. Наравно, дужина трајања новонастале сутуације је индивидуална за сваку породицу и зависи од способности породице да се прилагоди датим променама. У односу на друге уобичајене болести, МС је повезана са несразмерно великим социо-економским теретом. Породица и пријатељи играју виталну а често и тешку улогу у пружању подршке пацијентима да живе и функционишу код куће ${ }^{19}$.

У овој студији показано је да особе женског пола лакше подносе тегобе проузроковане мултиплом склерозом и имају бољи квалитет живота него мушкарци са истим клиничким обликом болести и идентичним тегобама, лечени истом терапијом. Највеће разлике забележене су у погледу перцепције чинилаца непосредног окружења оболелих: финансијских ресурса, слободе, физичке безбедности и сигурности, доступности и квалитета здравствене и социјалне заштите, породичног (кућног) окружења, могућности за стицање нових информација и вештина, могућностима и учешћу у рекреацији (активностима у слободно време), физичке околине (загађење, бука, клима и др.), и превоза.

\section{ЗАХВАЛНИЦА (ACKNOWLEDGMENT)}

The authors are greatful to World Health Organization for providing them with WHOQOL Bref and permission to use it in this research.

\section{ЛИТЕРАТУРА}

1. Koch-Henriksen N, Sørensen PS. The changing demographic pattern of multiple sclerosis epidemiology. Lancet Neurol 2010; 9: 520-32.

2. Koutsouraki E, Costa V, Baloyannis S. Epidemiology of multiple sclerosis in Europe: a review. Int Rev Psychiatry 2010; 22: 2-13.

3. Pekmezovic T, Jarebinski M, Drulovic J, Stojsavljevic N, Levic Z. Prevalence of multiple sclerosis in Belgrade, Yugoslavia. Acta Neurol Scand 2001; 104: 353-7.

4. Solari A. Role of health-related quality of life measures in the routine care of people with multiple sclerosis. Health Qual Life Outcomes 2005; 3:16.

5. Miller DM, Allen R. Quality of life in multiple sclerosis: determinants, measurement, and use in clinical practice. Curr Neurol Neurosci Rep 2010; 10: 397-406.

6. Chahraoui K, Bonin B, Couvreur G, Fromont A, Viegas N, Moreau T. Subjective quality of life profile in patients with multiple sclerosis. Rev Neurol 2010; 166: 8-9. 
7. Faul F, Erdfelder E, Lang AG, Buchner A. G*Power 3: A flexible statistical power analysis program for the social, behavioral, and biomedical sciences. Behav Res Methods 2007; 39: 175-91.

8. WHOQOL Group. Development of the World Health Organization WHOQOL-BREF quality of life assessment. Psychol Med 1998b; 28: 551-8.

9. Kikuchi H, Mifune N, Niino M, et al. Impact and characteristics of quality of life in Japanese patients with multiple sclerosis. Qual Life Res 2011; 20: 119-31.

10. Füvesi J, Bencsik K, Losonczi E, et al. Factors influencing the health-related quality of life in Hungarian multiple sclerosis patients. J Neurol Sci 2010; 293: 59-64.

11. Motl RW, Suh Y, Weikert M. Symptom cluster and quality of life in multiple sclerosis. J Pain Symptom Manage 2010; 39: 1025-32.

12. Szilasiova J, Krokavcova M, Gdovinova Z, Rosenberger J, Van Dijk JP. Quality of life in patients with multiple sclerosis in Eastern Slovakia. Disabil Rehabil 2011; 33: 1587-93.

13. Olsson M, Skär L, Söderberg S. Meanings of feeling well for women with multiple sclerosis. Qual Health Res 2010; 20: 1254-61.
14. McPheters JK, Sandberg JG. The relationship among couple relationship quality, physical functioning, and depression in multiple sclerosis patients and partners. Fam Syst Health 2010; 28: 48-68.

15. Grossman P, Kappos L, Gensicke H, et al. MS quality of life, depression, and fatigue improve after mindfulness training: a randomized trial. Neurology 2010; 75 : 1141-9.

16. Kouzoupis AB, Paparrigopoulos T, Soldatos M, Papadimitriou GN. The family of the multiple sclerosis patient: a psychosocial perspective.Int Rev Psychiatry 2010; 22: 83-9.

17. Pluta-Fuerst A, Petrovic K, Berger T, et al. Patient-reported quality of life in multiple sclerosis differs between cultures and countries: a cross-sectional $\mathrm{Au}-$ strian-German-Polish study. Mult Scler 2011; 17: 478-86.

18. Liedström E, Isaksson AK, Ahlström G. Quality of life in spite of an unpredictable future: the next of kin of patients with multiple sclerosis. J Neurosci Nurs 2010; 42: 331-41.

19. Dunn J. Impact of mobility impairment on the burden of caregiving in individuals with multiple sclerosis. Expert Rev Pharmacoeconomics Outcomes Res 2010; 10: 433-40. 